partners in the enterprise of bringing a scientific discovery into general use. The first is the scientific worker who discovers the new piece of knowledge. The second is the engineer who combines that new knowledge with existing knowledge and experience to make something which will work on whatever scale may be required. Third, there is the industrialist whose judgment, powers of organization and management provide the engineer with the conditions required for his activity and convert the enterprise into what is known as a going concern.

These three partners do not speak the same language, and are liable to misunderstand one another in a very dangerous way in their attempts at intercourse through the medium of garbled translation. A scientific worker is apt to view with impatience the insistence of the industrialist upon the fulfilment of certain practical conditions before he is ready to bring his resources and organizing capacity to bear on a new discovery. On the other hand, the scientific man's attempt to interpret in concrete terms of commercial production what is really a new way of thinking about the world, is apt to convey either an impression of undue optimism or else of mere vagueness and muddle. Is it then the engineer who can serve as the intermediary between the man of science and the industrialist ? This would be a mistaken solution, for engineers are essentially conservative. They rightly prefer to rely on estab. lished practice or the minimum departure from it to meet the requirements of a given problem. It is the engineer's duty so far as possible to minimize risks.

The position becomes clearer when the characteristice of a successful industrialist are examined. $\mathrm{He}$ must have imagination and be receptive to new ideas. Above all, he must have a capacity for seeing the possibilities inherent in a situation earlier and more clearly than his competitors. He must have judgment to weigh successfully the favourable and the adverse factors in an enterprise. In other words, he must be able to see not only the possibilities but also the difficulties in a realistic way.

Now these are just the qualities which should be applied to a new piece of scientific knowledge if it is to be used rapidly to the greatest effect. It is by combining the outlook of the man of science with that of the industrialist that the significance of a new discovery can best be gauged. It is only rarely that a scientific man has also a natural capacity for industrial insight and judgment, and is able himself to direct his work into productive channels. The conclusion is therefore reached that the man of science and industrialist are natural allies. They have more in common than either usually can appreciate, but it is difficult for them to wdrk together not merely because they speak different languages but also because they deal with different kinds of facts. Yet any industry, where the industrialists and scientific men really come together, will make technical progress of a kind that has not been seen since the beginning of the industrial epoch. This cannot be achieved by attempts on the part of the scientific workers to popularize their ideas, or by industrialists seeking to gain a smattering of science. It can only come if scientific men take the trouble to study and understand the kinds of facts which form the subjectmatter of industrial activity, and also if the industrialists try to understand what is meant by the formulation of a new scientific hypothesis. Neither of these two things is so difficult as might be thought. The mistake that is made at present when the man of science tries to explain his work to industry, is that he tends to describe experiments and observations, to give numerical examples, or attempts to forecast some practical application. He does not try to convey the meaning of his work, the new point of view which he has reached. This is what really matters in the scientific method, for this is the true creative work which the man of science alone can do.

\section{THE ARGENTINE EARTHQUAKE}

\section{BY ERNEST TILLOTSON}

$\mathrm{O}^{\mathrm{N}}$ January 15 at about 8.51 p.m. (local time) one of the strongest earthquakes of Argentine histery occurred in the Andean Province of San Juan. The epicentre of the earthquake was near the chief town in the province, San Juan, which is situated at latitude $31^{\circ} 38^{\prime} \mathrm{S}$., longitude $68^{\circ} 38^{\prime} \mathrm{W}$., and at this place as well as in the nearby villages there was great destruction of property and loss of life. In addition to San Juan Province, the Provinces of Cordoba, Mendoza and Larioja were affected, the latter seriously. The shock was felt throughout most of the remainder of the Argentine, and also in Chile and in Uruguay. It was recorded on seismographs at many observatories throughout the world, including some in Great Britain. At La Plata it was recorded very strongly, and at Buenos Aires the recording suddenly ceased nearly as soon as it began owing to the violent, large amplitude earth waves being too great for the pendulum, which became unhinged. The recording needles of the instrument were also broken.

In San Juan, a city with a population of about eighty thousand people, about two thirds of the buildings immediately collapsed, and others were damaged in varying degrees. Among the large buildings thus affected were the cathedral, numerous churches, Government House, municipal buildings, the railway station and the post office. Fissures and fault cracks appeared in the streets. Electric cables were broken, gas.mains were shattered, water pipes were burst open, and telephone communication within the city and to the outside world ceased. Roads, especially the narrow ones, were blocked with the debris of crashed buildings, and rail traffic was stopped by fissures, fallen debris and twisted rails. In the city fires raged, having been started by the shaking of hot coals from the fireplaces, by gas escapes and by electric short circuits. Even if the fire brigades could have got to them, there would have been no water supply, and so they burned themselves out unchecked. Unfortunately, at the time many people were in cafés, cinemas and restaurants and were trapped in the buildings and narrow streets. The death roll is undoubtedly high, and three thousand bodies have so far been found and burned. More than another three thousand are injured, and when the casualties in the surrounding villages are counted the death-roll may be as high as five thousand. Fortunately rail communication with Mendoza was quickly resumed, and radio communication with the city was found possible. Drinking water was sent from Mendoza, one hundred miles away. Many of the people are now living in tents and relief work is in progress. San Juan is to be completely evacuated and cleared, and when it is rebuilt it will be spacious and the buildings will be of earthquake-proof design. The evacuation would 
appear inevitable as aftershocks, including a very violent one some thirty-six hours after the first earthquake, caused buildings previously damaged to collapse, and damaged most of the remaining ones.

In Buenos Aires in the eastern Argentine the original earthquake was sufficiently pronounced to sway street lamps. The shock was also distinctly noticeable in the upper stories of sky-scrapers. The last strong earthquake which affected San Juan and destroyed some property occurred on October 27, 1894. On that occasion La Rioja was also affected, though the shock was not so.severe as the present one. The Argentine is definitely a country where earthquakes are liable to occur from time to time, though it is not so greatly affected as its neighbour
Chile. It is that part of the Argentine nearest to the Andes Mountain Chain which is most affected and not so much the eastern plains. The Andes form part of the great circum-Pacific belt of instability, round which more than half of the world's great earth. quakes occur. Although earthquakes of destructive violence have happened from time to time in the twentieth century in the Argentine, they have usually been centred away from densely populated areas and towns. In the nineteenth century there were several outstandingly destructive shocks. On April 9, 1849, San Luis was destroyed. On March 20, 1861, Mendoza experienced widespread destruction, and on October 22, 1871, Jujuy and Oran suffered this same fate, to name a few outstanding examples.

\section{NEWS and VIEWS}

\section{Sir Richard Gregory, Bart., F.R.S.}

JANUARY 29 marks the eightieth birthday of Sir Richard Gregory, president of the British Association and formerly editor of NATURE. To many who have known him, this may come as a surprise, for his energy and alertness seem unabated with the passage of years. Upon his retirement from the editorship of NATURE at the end of 1938, Sir Richard gave scientific men a message which in some ways may be regarded as his own philosophy of life (see NatuRE, January 7, $1939, \mathrm{p} .1)$. In it he shows his profound belief in the significance for the future of mankind of scientific progress and its application to human affairs. His labours to this end were fittingly acknowledged by his election in 1933 to the Royal Society, under the special rule which permits election to the fellowship for "conspicuous service to the cause of science".

But Sir Richard did not retire from public life when he relinquished his editorial post at the age of seventy-five; his new leisure was quickly occupied with other interests. During the forty-five years of his association with NATURE, he had always taken a prominent part in the work of the British Association, and in particular of Section $\mathrm{L}$ (Education), which he served in many capacities, becoming president in 1922. Finally, at the ill-fated meeting at Dundee in 1939, which had to be abandoned through the outbreak of war, he was elected president of the British Association for 1940 (see NATuRE, September 9, 1939 , p. 472), and has, of course, remained in that office since. Due largely to his initiative, the Association, through the new Division for the Social and International Relations of Science, has, in spite of wartime conditions, managed to hold meetings of limited scope in Reading, Manchester, and London. Sir Richard Gregory has made many friends on his visits to South Africa (with the British Association), to India and to the United States, who will feel a particular interest as they join with other scientific men in congratulating him upon his past achievements and sending him their good wishes for the future.

\section{Colonial Products Research Council: Report}

THE first interim report of the Colonial Products Research Council states that the procedure adopted, which was modelled on and adapted from that of the Department of Scientific and Industrial Research, the Medical Research Council and the Agricultural Research Council, is to make the fullest possible use of existing research facilities in universities and other institutions, delegating to them the investigation of specific problems on terms mutually arranged. Researches already planned or initiated in this way include investigations on sucrose and sucrose derivatives under Prof. W. N. Haworth at the University of Birmingham; on eugenol and isoeugenol under Prof. G. R. Clemo at the University of Durham; on lime oil, lime juice and citrus under Prof. I. M. Heilbron at the Imperial College of Science and Technology, London; on fixed oils and fats under Prof. T. P. Hilditch at the University of Liverpool and Dr. Ida Smedley-MacLean at the Lister Institute ; on caffeine and theobromine under Prof. A. R. Todd at the University of Manchester; on petroleum products under Sir Robert Robinson at the Dyson Perrins Laboratory, Oxford ; and on the production of ergosterol at the Chemical Research Laboratory under Dr. A. C. Thaysen. The Council is also engaged in reviewing the field of research into vegetable drugs. The Director of Research has been accommodated at the Imperial Institute by the courtesy of Sir Harry Lindsay. While the function of the Council is to organize and sponsor fundamental and applied researches on Colonial commodities, with the primary object of finding new uses for them, the Institute will continue its chemical investigations of Empire raw materials in accordance with its statutory obligations and will furnish information to producers and potential customers on sources of supply, markets, the preparation of commodities for commercial and industrial use, and the economic possibilities for any given commodity, etc.

\section{The Education Question: a Biological Approach}

The inaugural address at the University of Leeds School of Medicine delivered last autumn was by Sir John Graham Kerr, who announced as his subject "Medicine and Education". To what extent the substance of the address answered the expectations of the audience is perhaps doubtful, but there is no doubt whatever that it answered to one of the needs of the hour. Sir John pointed out that, among primitive peoples, a boy becomes a highly trained observer by eye and ear, he acquires the ability to interpret rapidly and correctly what he observes and he learns to keep his wits constantly alert. As boyhood passes into adolescence, he accompanies his elders on their expeditions, and his education continues as before. That the education of to-day has departed so widely from its original 